http://dx.doi.org/10.18778/1508-1117.25.03

Simone Marques de Sousa Safe, Staël de Alvarenga Pereira Costa

\title{
FRINGE BELT ANALYSIS: A METHOD FOR CONFIRMING THE ESTABLISHMENT OF THE HISTORICAL BOUNDARIES OF RABAT
}

\begin{abstract}
Fringe belts, extensive areas of low density and wide open spaces designated for institutional use, are a morphological element in the urban landscape. Rabat, capital of Morocco, conceived during the French protectorate, received in 2012, a UNESCO World Heritage title for representing a modern urban planning model that integrates an open space system with its historical nucleus. Nonetheless, criterion (v) - to be an outstanding example of a traditional human settlement, which is representative of a culture (or cultures), or human interaction with the environment - was deemed grounds for rejecting Rabat's nomination because the candidate presented seemed to be fragmented and showed a lack of a relationship between property and environment, according to the ICOMOS report. This study considers the Kasbah of Oudayas to be a unique and outstanding example of a traditional human settlement, in contrast to those cases presented in 2012. The aim of this study is to investigate the evolution of urban Rabat according to the morphological periods of development, in order to, ascertain whether or not the fringe belts can reveal the historic areas in which the city has evolved over time. It also seeks to understand how fringe belts may contribute to confirming the Kasbah of Oudayas as the first Islamic urban nucleus in the capital. As such, it is hoped that the paper may: assist practitioners and academics in the fields of urban morphology and heritage; provide initial insights into how to investigate outstanding traditional human settlements; reveal the architectural, historical and cultural value of such sites; demonstrate how the application and dissemination of a methodology may open new perspectives for studies on the subject.
\end{abstract}

Keywords Urban morphology, fringe belts, urban evolution, Rabat, UNESCO World Heritage. 


\section{Introduction}

The Kingdom of Morocco possesses nine cultural entities designated as World Heritage sites by UNESCO, the most recent being Rabat (the capital) which was selected for its symbolic, cultural and diversified traditions. Located in the northwest of the country, on the north-eastern Atlantic coast where the Bouregreg River meets the sea, the site faces Salé, its "twin" city.

To be included on the World Heritage List, sites must present outstanding universal value and fulfil at least one of the ten selection criteria established by UNESCO. The information, hereby presented, is part of the report produced by the Kingdom of Morocco and presented to UNESCO in 2011 in order to have its cultural heritage sites evaluated and included on the list. Rabat fulfilled criteria (ii) and (iv) ${ }^{1}$, according to the International Council on Monuments and Sites (Icomos) 1401 report.

Criterias (ii) and (iv) were fulfilled by the fact that Rabat has been considered a unique example of a modernist $20^{\text {th }}$ century capital possessing a legacy of diverse and successive cultures. Thus occupation of the city shows evidence of continuity with traces from various periods, together with, the presence of monuments reflecting African, Mediterranean, Eastern and European cultures. As a result of the European and Moroccan elements, the site has acquired a distinct character, while its capacity to demonstrate lasting historical, cultural and social co-existence with the urban landscape demonstrates the Genius Loci of the site.

However, according to the 1401 Icomos evaluation, the city was not worthy of Criteria $(\mathrm{v})^{2}$ status as the property bears insufficient testimony to its relationship with a territory to fully justify this criterion. Firstly it is fragmented, sometimes on a very small scale, which bears scant testimony to a privileged relationship with a particular environment. Secondly, the relationship to the estuary, which was the basis of the geographic determination of the place, and the function as a port, are not present in the nominated property, or only very marginally. For this to have been the case, it would have been necessary to take the Rabat-Salé ensemble together as a whole, and consider the surviving vestiges of the port ${ }^{3}$.

${ }^{1}$ (ii) to exhibit an important interchange of human values, over a span of time or within a cultural area of the world, on developments in architecture or technology, monumental arts, town-planning or landscape design; (iv) to be an outstanding example of a type of building, architectural or technological ensemble or landscape which illustrates (a) significant stage(s) in human history (http://whc.unesco.org/en/criteria).

${ }^{2}(\mathrm{v})$ - be an outstanding example of a traditional human settlement, land-use or sea-use which is representative of a culture (or cultures), or human interaction with the environment especially when it has become vulnerable under the impact of irreversible (http:// whc.unesco.org/en/criteria).

${ }^{3} \mathrm{http}: / /$ whc.unesco.org/archive/advisory_body_evaluation/1401.pdf. 
In contention to such an evaluation, this paper argues that analysing the existence of fringe belts would demonstrate not only the different stages of urban development, showing the settlement's relationship with the territory, but also an hierarchy of the traditional settlements (Kasbah of Oudayas and Medina of Rabat), demonstrating that there is no fragmentation neither privileged relationship with a particular environment, as the fringe belts reveal the regions as an ensemble between the different stages of development. Fringe belt can also help to understand that the vestiges of the port are still presented at the same geographical place, except that it is transformed and has no longer the same use.

\section{English School of Urban Morphology's methods: Urban Evolution and Fringe Belt}

The study of urban evolution is a theme initially pioneered by the English School of Urban Morphology and, as such, it seeks to demonstrate the relationship between the cultural assets and the territory they occupy by tracing and mapping out the morphological periods of urban development. The School has furthermore incorporated a standard evaluation of city fringe belts in its approach and has sought to identify the interaction between the formation of spatial processes and the transformation of the urban landscape.

M.R.G. Conzen (1969) has recognized the fringe belt phenomenon in Great Britain in his detailed morphological study over medieval town, Alnwick. His conceptual contribution in this work was to incorporate fringe belt patterns interacting with the spatial shaping process and its urban landscape transformation. He has also formally define fringe belt: „A belt-like zone originating from the temporarily or very slowly advancing fringe of a town and composed of a characteristic mixture of land-use units initially seeking peripheral location" (Conzen 1969).

According to Conzen's work in Alnwick (1969), three distinct fringe belts were mapped out and classified as inner (IFB), middle (MFB) and outer (OFB) with each classification corresponding consecutively to the fixation, expansion and consolidation stages. M.R.G. Fringe belts are classified according to the historical periods. Normally, the inner fringe belt is associate to medieval town walls, which was called by M.R.G. Conzen as fixation lines: elements that induce the development of fringe belts into spaces along them. The middle fringe belt refers to the second ring located after the first expansion, in the first suburban area. And the outer fringe belt is the area in the urban periphery, scattered and poorly defined sites, formed during the twentieth century. Conzen's work over Alnwick is presented in Fig. 1. 


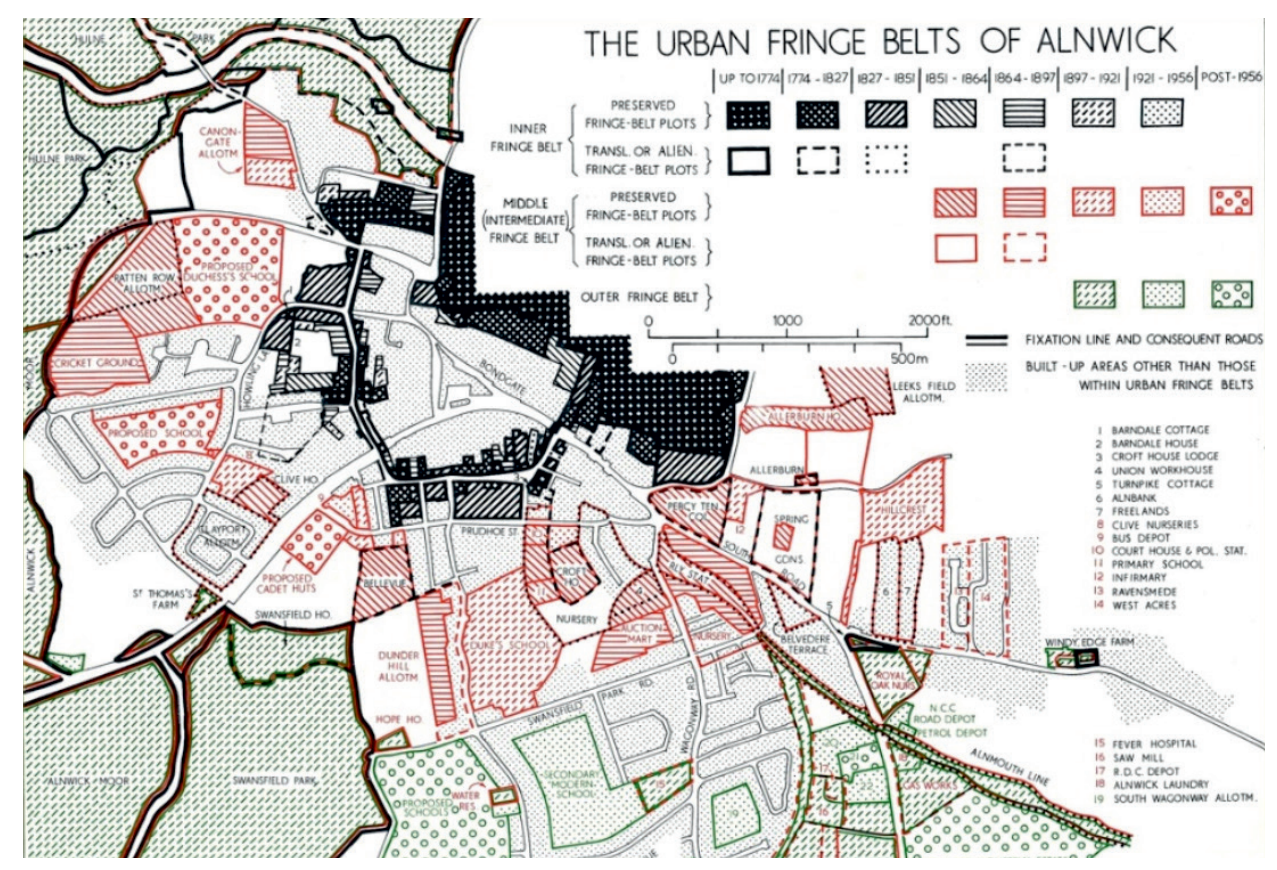

Fig. 1. Urban fringe belts of Alnwick

Source: M.R.G. Conzen (1969)

The fringe belt formation occurs in cycles. One can assert that an inner fringe belt always have their origin classification as an outer fringe belt. Initially, there is the formation of only one fringe belt classified as outer. Than a second fringe belt is formed, being classified as outer, passing the past one as inner. When a third fringe belt is formed, the oldest remains classified as inner, the second as a middle and the third, more recent, as outer. Therefore, this classification is associated with the formation of new fringe belts over time. Fig. 2 presents the classification model that embodies the method.

In this paper the same methodology will be employed in the study undertaken of Rabat.

Thus, in the ancient Moroccan city, morphological periods have been identified based on the historical references and research carried out by Dr. Es-Semmar (Director of Heritage at the Bouregreg Agency) on the urban evolution of Rabat-Salé over the past twenty-five centuries. In this analysis, we plan to identify the fringe belts of Rabat typically formed, according to the approach, by extensive areas of low density and wide open spaces designated for institutional use. 


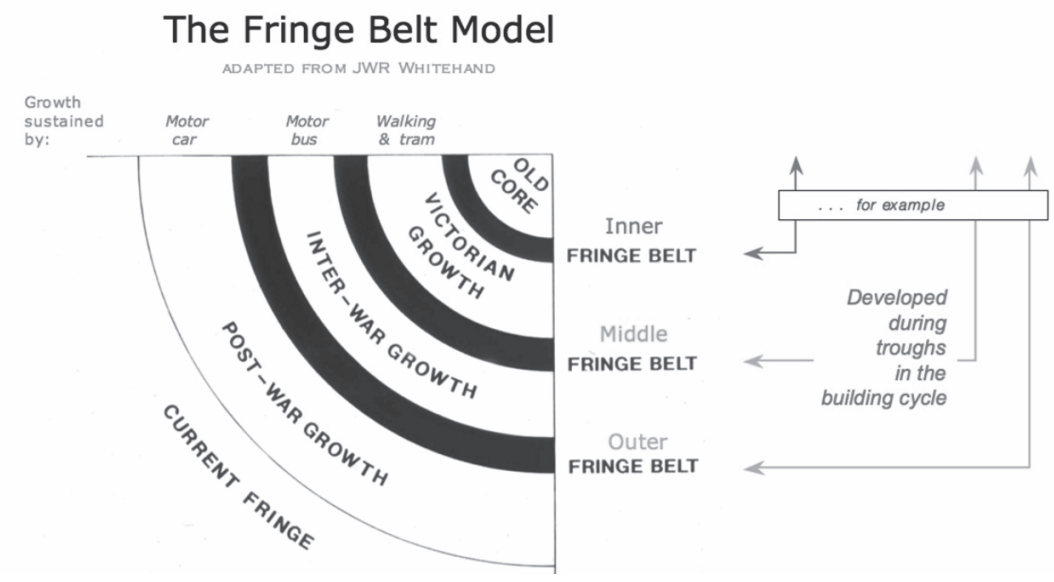

Fig. 2. The fringe belt model according to historical periods in Great Britain Source: M.P. Conzen (2009)

\section{The Urban Evolution of Rabat}

The morphological periods are based on historical and evolutionary periods which according to M.P. Conzen (2004) should be differentiated. The geographer defines historical periods as those demarcated by facts in which it is possible to establish dates, such as, reigns, empires, and republican periods among others. In addition, it is contended that evolutionary periods represent the synthesis between historical facts and materialized innovations on the urban landscape which in turn define formal characteristics. Such innovation could represent the start or closure of an economic, social, political or/and cultural era, and are identified by specific formal characteristics.

In Morocco, the historical periods considered relevant are: $\mathrm{A}$ - the period before Islamization ( $5^{\text {th }}$ century $\mathrm{BC}$ to $5^{\text {th }}$ century); $\mathrm{B}$ - the influence of the Muslin Berbers $\left(6^{\text {th }}\right.$ century to $16^{\text {th }}$ century $)$ and $\mathrm{C}$ - the Arabian influence $\left(16^{\text {th }}\right.$ century to $21^{\text {st }}$ century).

\section{A - Before "Islamization" ( $5^{\text {th }}$ century BC to $5^{\text {th }}$ century): Phoenicians, Carthaginians and Romans}

Two Phoenician colonies of the current Kingdom of Morocco - Lixus (Larache), in the north, and Mogador (Essaouira), in the south - facilitated the connecting route between North Africa and Spain while Cartago had not yet domain over the region of the western Mediterranean bank. However, due to the navigational difficulties of the time, other supporting trading posts were founded between both of them, such as Sala, and also Russandir, Tamuda, Tingis, Tchemmich, Banasa and Rusibis. 
Traces of Phoenician and Carthaginian archaeological occupation cannot be found in Rabat, although according to M. Es-Semmar (2011), there is evidence in ancient texts which refer to the commerce conducted between the Phoenicians and the indigenous Amazigh tribe, around the $5^{\text {th }}$ century $\mathrm{BC}$ and the subsequent exploitation by the Carthaginians of the same commercial area, during the $3^{\text {rd }}$ century BC. The only archaeological traces that can be found on this site are then from the Roman Empire and they correspond to a military fortification that was also used for commercial purposes during the first century BC. Around two hundred years after this period, Sala Colonial emerged as the first urban settlement, in the first century.

The Mauretania Tingitana region was abandoned at the end of the $3^{\text {rd }}$ century, but Sala (currently Chellah) remained under Roman domination during a less active period up to the end of the $4^{\text {th }}$ century. It then entered a rather historically obscure period in which no traces were left.

\section{B - Berbers - The Islamization of the Kingdom of Morocco ( $6^{\text {th }}$ century to $16^{\text {th }}$ century)}

Between the $8^{\text {th }}$ and $11^{\text {th }}$ century, the emergence of the Muslin-Berbers enabled the rise of the Almoravid people, who came from the Sahara region during a religious reformation (Caillé 2006). The Almoravid empire was founded by Youssof Ben Tachfin and lasted for about seventy five years. The conflicts between Arabs and Berbers were long and, historical and the literature offers little analytical consensus. In this paper, we follow B. Lugan (2011) and J. Brignon et al. (1987), who contend that the occupation of the Maghrebis was atypical in comparison to other Arabic conquests. The occupation of Maghreb took over half a century (Brignon et al. 1987) and the conflict between Arab-Muslims and Berbers was longer whilst this period also marked the Islamisation of the region.

With regards to urban development, this era (the Idrissid Dynasty 789-808) marks the foundation of Fez which remained the capital until the rise of the Almoravid Empire $\left(10^{\text {th }}\right)$. During the Almoravid dynasty two other towns were founded: Meknes and Marrakesh. The latter became the capital of the empire until the rise of the Merinide dynasty $\left(13^{\text {th }}\right.$ century). In Rabat, there are archaeological vestiges of the ancient city of Almoravids which was abandoned to make way for the construction of a new fortress in the early $12^{\text {th }}$ century located on the southern promontory of the estuary. This was built to withstand growing military pressure from the Almohads whose conquest eventually took place in the mid- $12^{\text {th }}$ century, transforming the fort into a fortified settlement, which today has become the Kasbah of Oudayas. 


\section{C - The Arabians $\left(16^{\text {th }}\right.$ century to $21^{\text {st }}$ century)}

The beginning of the sixteenth century was marked by crisis over the Moroccan territory due to the Iberian conquest in the west and the Turkish in the east. The Ottomans wanted supremacy over their Spanish opponents and tried to exert influence over Morocco. A new dynasty emerged - the Saadian, enabling a political, economic and intellectual renaissance. The Saadian were Arabs and, for the first time since the Idrissid dynasty, Morocco was ruled by a grouping other than the Berbers. The Saadian century was a period of urban development with Fès and Marrakesh becoming intellectually dominant and established cultural centres.

Each era possessed a political administration that forced changes in social life. In Rabat-Salé, during period A, two occupations were witnessed: the Phoenicians together with the Cartago and the Romans. Period B started with the Almoravid Empire ( $10^{\text {th }}$ century), followed by the Almohads ( $11^{\text {th }}$ century to $12^{\text {th }}$ century) and the Merinid dynasty ( $13^{\text {th }}$ century to $16^{\text {th }}$ century). During period $\mathrm{C}$, there were two major dynasties in power: the Saadian ( $17^{\text {th }}$ century) and the Alaouite $\left(17^{\text {th }}\right.$ century to $21^{\text {st }}$ century).

Twelve evolutionary periods have been identified based on the evolution of the urban landscape of Rabat-Salé:

1. The Cartago and Roman Empire - Sala Colonia $\left(\mathrm{B}-5^{\text {th }}\right.$ century $-5^{\text {th }}$ century);

2. The Almoravid Empire (1100 to 1150);

3. The Almohad Empire: $1^{\text {st }}$ Caliph Abdelmoumen (1150-1163);

4. The Almohad Empire: $2^{\text {nd }}$ Caliph Youssef (1163) and $3^{\text {rd }}$ Caliph Yacoub Al Mansur (1187);

5. The Merinid dynasty (1253-1609);

6. The Saadian dynasty - the Moors period (1609-1666);

7. The Alaouite dynasty - Golden Age (1666-1727);

8. The Alaouite dynasty - Expansion and Consolidation (1757-1912);

9. The French Protectorate - Rabat capital (1912-1941);

10. The French Protectorate - Expansion (1941-1956);

11. The Alaouite dynasty - Independence: Rabat-Sale Master Plan 1971-72 (1956-1990);

12. The Alaouite dynasty - Rabat-Sale Master Plan 1995 (1990-2014).

The morphological periods represent the synthesis between each historical and evolutionary period. A synthesis of Rabat's morphological periods is presented in Table 1. 
Table 1

Chart with morphological periods of Rabat

\begin{tabular}{|c|c|c|c|}
\hline \multicolumn{3}{|c|}{ Historical and evolutionary periods } & \multirow{2}{*}{$\begin{array}{c}\text { Morphological periods } \\
\text { Classical Period } \\
\left(\mathbf{1}^{\text {st }}-\mathbf{3}^{\text {rd }} \text { century }\right)\end{array}$} \\
\hline $\begin{array}{c}\text { Before } \\
\text { Islamization } \\
\left(5^{\text {th }} \text { century b.c }\right. \\
\left.-5^{\text {th }} \text { century }\right) \\
\end{array}$ & $\begin{array}{l}\text { Phoenicians, } \\
\text { Carthaginians } \\
\text { and Romans } \\
\text { Periods } \\
\end{array}$ & $\begin{array}{l}5^{\text {th }} \text { century b.c } \\
-3^{\text {rd }} \text { century }\end{array}$ & \\
\hline \multirow{3}{*}{$\begin{array}{l}\text { Berbers - } \\
\text { The Islamisa- } \\
\text { tion of } \\
\text { the Kingdom } \\
\text { of Morocco } \\
\left(6^{\text {th }}-16^{\text {th }}\right. \\
\text { century) }\end{array}$} & $\begin{array}{l}\text { Almoravid } \\
\text { Empire }\end{array}$ & $1100-1150$ & $\begin{array}{c}\text { Ribat Almoravid Period } \\
(1100-1150)\end{array}$ \\
\hline & $\begin{array}{l}\text { Almohad } \\
\text { Empire }\end{array}$ & $\begin{array}{c}1150-1163 \\
1^{\circ} \text { Calif } \\
\end{array}$ & $\begin{array}{c}1^{0} \text { Ribat Al Fath Period } \\
(1150-1163)\end{array}$ \\
\hline & $\begin{array}{l}\text { Merinid } \\
\text { Dynasty }\end{array}$ & $\begin{array}{c}1163-1253 \\
2^{\circ} \text { e } 3^{\circ} \text { Califs }\end{array}$ & $\begin{array}{c}2^{\text {nd }} \text { Ribat Al Fath Period } \\
(1163-1253)\end{array}$ \\
\hline \multirow{8}{*}{$\begin{array}{l}\text { The Arabians } \\
\left(16^{\text {th }}-21^{\text {st }}\right. \\
\text { century })\end{array}$} & $\begin{array}{c}\text { The Saadian } \\
\text { Dynasty } 1554 \\
\text { to } 1650 \\
\end{array}$ & $1253-1609$ & $\begin{array}{l}\text { Aribat Al Mobarak Period } \\
\text { (1253-1609) }\end{array}$ \\
\hline & \multirow{7}{*}{$\begin{array}{c}\text { The Alaouite } \\
\text { Dynasty }\end{array}$} & $1609-1666$ & $\begin{array}{l}\text { The Moors Period } \\
\text { (1609-1666) }\end{array}$ \\
\hline & & $\begin{array}{c}\text { 1666-1727 } \\
\text { Moulay Rachid } \\
\text { - Moulay Ismail }\end{array}$ & $\begin{array}{l}\text { Golden Age Period } \\
\quad(1666-1727)\end{array}$ \\
\hline & & $\begin{array}{c}\text { Sultan Sidi Moham- } \\
\text { med ben Abdallah - } \\
\text { 1757- Sultan Moulay } \\
\text { Abderrahmane Ben } \\
\text { Hicham } 1790 \text { - Sul- } \\
\text { tan Moulay Slimane } \\
1912 \\
\end{array}$ & $\begin{array}{c}\text { Expansion } \\
\text { and Consolidation Period } \\
(1757-1912)\end{array}$ \\
\hline & & $\begin{array}{c}\text { 1912-1941 } \\
\text { Rabat: capital }\end{array}$ & $\begin{array}{c}\text { French Protectorate Period } \\
\text { - Prost urban plan } \\
(1912-1941) \\
\end{array}$ \\
\hline & & $\begin{array}{l}\text { 1941-1956 } \\
\text { King Hassan II }\end{array}$ & $\begin{array}{c}\text { Period of expansion: } \\
\text { Ecochard urban plan } \\
(1956-1972) \\
\end{array}$ \\
\hline & & $\begin{array}{c}\text { 1956-1990 } \\
\text { King Hassan II }\end{array}$ & $\begin{array}{c}\text { Independence: Rabat-Sale urban } \\
\text { master plan of 1971-72 }\end{array}$ \\
\hline & & $\begin{array}{c}\text { 1990-2014 } \\
\text { King Mohammed VI }\end{array}$ & $\begin{array}{c}\text { Rabat-Sale urban master plan } \\
\text { of } 1991\end{array}$ \\
\hline
\end{tabular}

Source: conceived by the authors based on the historical bibliography (April, 2014). 


\subsection{Morphological periods of Rabat}

The morphological periods that reveal the development of the city are presented on three methodological bases respectively related to the historical, evolutionary and morphological periods: historical event, innovation and urban form.

In order to organize the understanding of the fringe belts formation, this item has been divided in three sub-sections: Fixation Stage $-1^{\text {st }}$ to $3^{\text {rd }}$ morphological periods and Inner fringe belt; Expansion Stage $-4^{\text {th }}$ to $9^{\text {th }}$ morphological periods and middle fringe belt; Consolidation Stage and $10^{\text {th }}$ to $12^{\text {th }}$ morphological period. Thus we start by presenting a map of the evolution of urban form of Rabat that illustrate the morphological periods (Fig. 3).
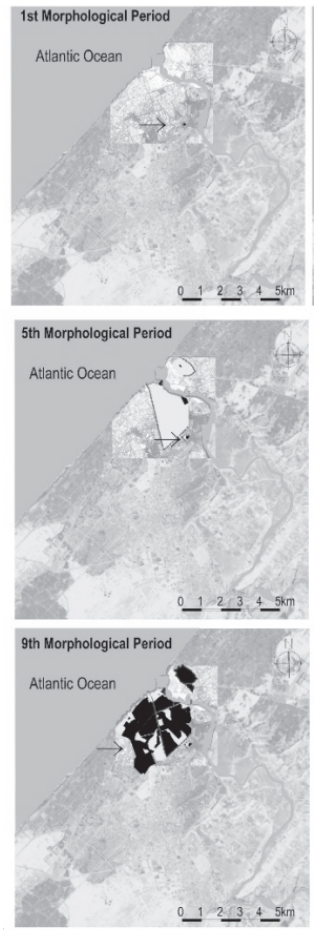
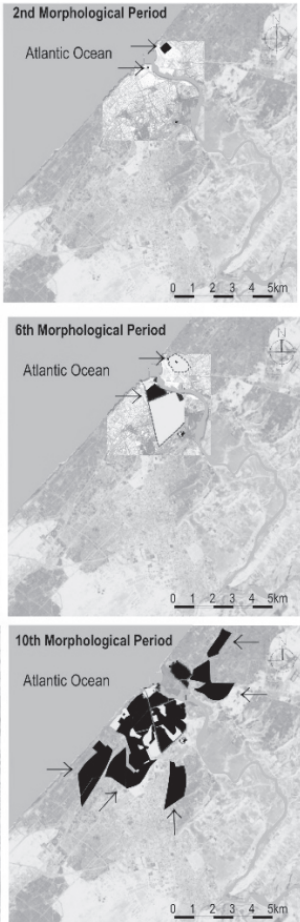
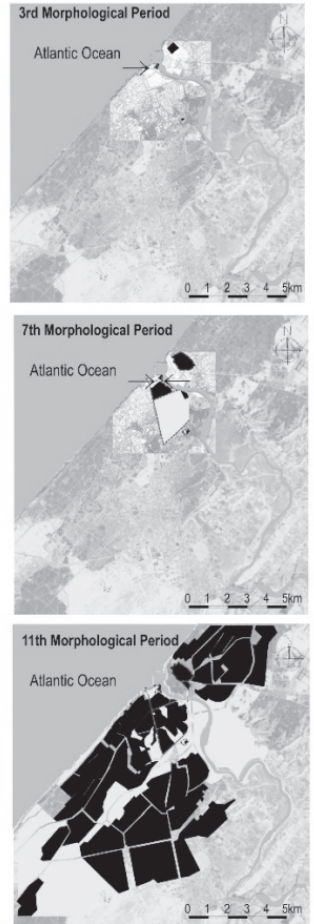
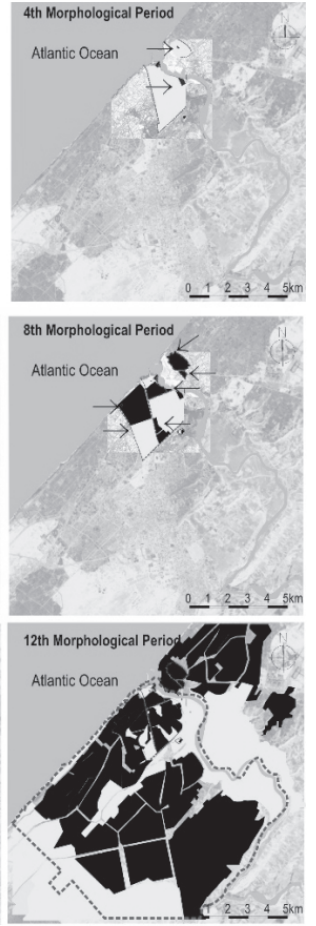

Fig. 3. Map representing the evolution of the urban form of Rabat

Source: Map produced by the authors based on historical research, 2014

The first sub-section contains the first three morphological periods (Table 2) and a map of the IFB (Fig. 4). 
Chart with $1^{\text {st }}$ to $3^{\text {rd }}$ morphological periods of Rabat

\begin{tabular}{|c|c|c|c|c|}
\hline $\begin{array}{l}\text { Morphologi- } \\
\text { cal Period }\end{array}$ & $\begin{array}{c}\text { Historical } \\
\text { event }\end{array}$ & Innovation & Urban form & Outline view \\
\hline $\begin{array}{l}1^{\text {st }} \text { Classical } \\
\text { Period } \\
\left(1^{\text {st }} \text { century }\right. \\
\left.-3^{\text {rd }} \text { century }\right)\end{array}$ & $\begin{array}{l}\text { The Roman } \\
\text { Empire } \\
\left(1^{\text {st }} \text { century }\right)\end{array}$ & $\begin{array}{c}\text { A trading settlement } \\
\text { which became } \\
\text { a town - the southern } \\
\text { capital of } \\
\text { Mauritania Tingitane } \\
\text { (the Roman admi- } \\
\text { nistrative centre of } \\
\text { North Africa) }\end{array}$ & $\begin{array}{l}\text { The urban settlement } \\
\text { of Sala Colonia } \\
\text { (in Rabat). The } \\
\text { Roman city was } \\
\text { based around } \\
\text { a fortified wall with } \\
\text { a triumphal arch, } \\
\text { a forum, a main } \\
\text { street, a basilica and } \\
\text { public baths }\end{array}$ & $\begin{array}{c}\text { All urban and } \\
\text { architectonical } \\
\text { development, } \\
\text { throughout the } \\
\text { following twenty } \\
\text { centuries, represen- } \\
\text { ted an extension of, } \\
\text { or continuity with, } \\
\text { this initial Roman } \\
\text { settlement }\end{array}$ \\
\hline $\begin{array}{l}2^{\text {nd: }} \text { Ribat* } \\
\text { Almoravid } \\
\text { Period } \\
(1100 \text { to } 1150) \\
* \text { Ribat } \\
\text { (military field) }\end{array}$ & $\begin{array}{l}\text { The } \\
\text { Almoravid } \\
\text { Empire }\end{array}$ & $\begin{array}{l}\text { Occupation of both } \\
\text { Bouregreg river } \\
\text { banks: On the right } \\
\text { bank, an extension } \\
\text { of the ancient town } \\
\text { of Sala; on the left } \\
\text { bank, the expansion } \\
\text { and foundation of } \\
\text { Ribat Tachfin (name } \\
\text { of their emporer) }\end{array}$ & $\begin{array}{l}\text { The city of Sala } \\
\text { (in Salé) and the } \\
\text { military field Ribat } \\
\text { Tachfin (in Rabat) } \\
\text { presented in Fig. } 2\end{array}$ & $\begin{array}{l}\text { Ribat Tachfin was } \\
\text { the first Islamic } \\
\text { occupation of the } \\
\text { estuary }\end{array}$ \\
\hline $\begin{array}{l}3^{\text {rd }}: 1^{\circ} \text { Ribat } \\
\text { Al Fath* } \\
\text { Period } \\
(1150-1163) \\
\text { * Name given } \\
\text { to the expan- } \\
\text { ded city } \\
\text { (Kasbah of } \\
\text { Mehdiya }+ \\
\text { Salé) }\end{array}$ & $\begin{array}{c}\text { The } \\
\text { Almohad } \\
\text { Empire } \\
-1^{\text {st }} \text { Caliph } \\
\text { Abdelmoumen }\end{array}$ & \begin{tabular}{|} 
The Bani Ifren city \\
wall was demo- \\
lished on the right \\
river bank and \\
Almoravide's \\
Tachfin Ribat was \\
pulled down, on the \\
left river bank. \\
Ribat Tachfin was \\
replaced by the \\
Kasbah of Mehdiya, \\
the urban core of the \\
new planned city
\end{tabular} & $\begin{array}{l}\text { Kasbah of Mehdiya: } \\
\text { The urban organi- } \\
\text { zation is structured } \\
\text { around the main } \\
\text { artery from which } \\
\text { the mosque is central } \\
\text { to the public space }\end{array}$ & $\begin{array}{l}\text { Ribat Tachfin was } \\
\text { replaced by the } \\
\text { Kasbah of Mehdiya, } \\
\text { the urban core of the } \\
\text { new planned city. } \\
\text { Throughout this } \\
\text { period, the Almohads } \\
\text { had the intention of } \\
\text { turning Rabat into the } \\
\text { third imperial capital, } \\
\text { after Marrakesh and } \\
\text { Seville }\end{array}$ \\
\hline
\end{tabular}

Source: conceived by the authors based on S. Safe, S. Pereira Costa (2014). April, 2016.

These first periods show the establishment of the first Islamic urban settlement. With all transition of power, one can understand the need for military fortification, known in Arabic as Kasbah. Around this fort walls (fixation line), the cemetery was 
placed, according to their religion, outside the city walls. The reflection in the urban form was the creation of an internal group of units of inner fringe belt, located around the Kasbah of Mehdiya (known as Kasbah of Oudayas in the present days) (Fig. 4).

At this time there were more open spaces along with the cemetery than consolidated institutions. Following, this inner belt gained other uses (the cemetery remains until 2016; the fort becomes a prison and then a museum; the Royal Palace (12 ${ }^{\text {th }}$ century) becomes a public garden and museum (2016); the old port gains recreational use as a Marina river front (2016) and it is possible to confirm the maintenance of the transformed port site as a inner fringe belt.

In the map below (Fig. 4) the inner fringe belt is represented with the land use modification along the years.

Year: 1163

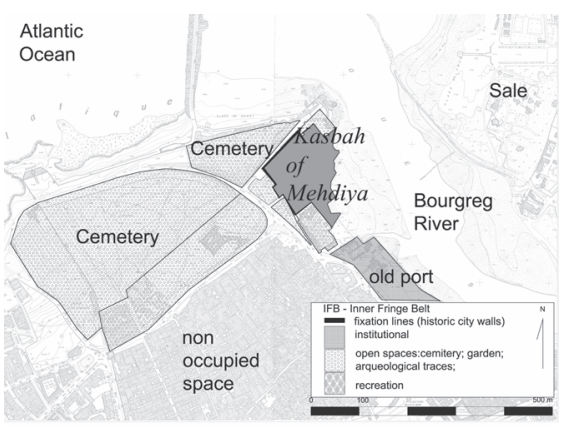

Year: 1727

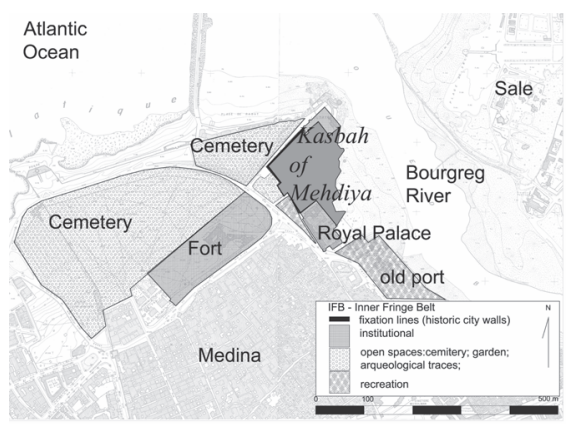

Year: 2016

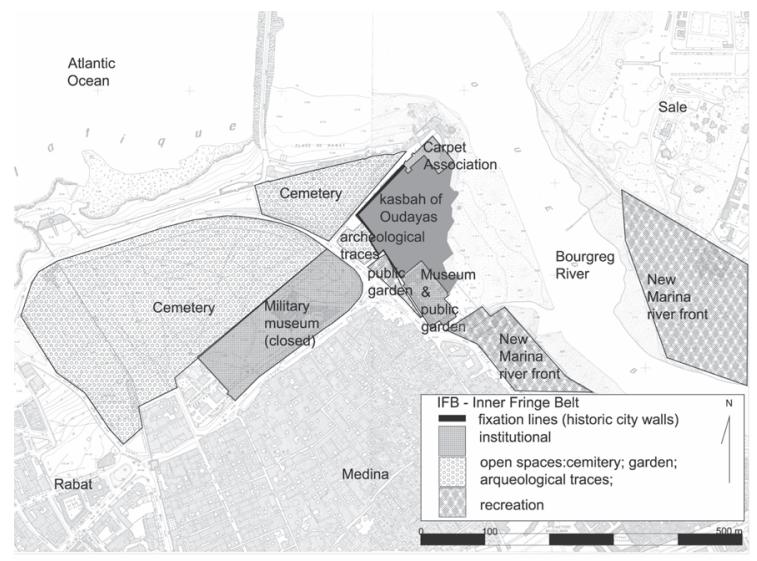

Fig. 4. Fixation Stage - Inner fringe belt formation (IFB)

Source: Map produced by the author based on historical research, 2016 
The second sub-section contains six of the morphological periods (Table 3) and a map of the MFB (Fig. 5).

Table 3

Chart with $4^{\text {th }}$ to $9^{\text {th }}$ morphological periods of Rabat

\begin{tabular}{|c|c|c|c|c|}
\hline $\begin{array}{l}\text { Morphologi- } \\
\text { cal period }\end{array}$ & $\begin{array}{c}\text { Historical } \\
\text { event }\end{array}$ & Innovation & Urban form & Outline view \\
\hline $\begin{array}{c}4^{\text {th }}: 2^{\text {nd }} \\
\text { Ribat Al } \\
\text { Fath Period } \\
(1163-1253)\end{array}$ & $\begin{array}{c}\text { The Almo- } \\
\text { had Empire } \\
-2^{\text {nd }} \text { Caliph } \\
\text { Youssef } \\
(1163) \text { and } \\
3^{\text {rd }} \text { Caliph } \\
\text { Yacoub } \\
\text { Al Mansur } \\
(1187)\end{array}$ & $\begin{array}{l}\text { The Completion of the } \\
\text { town of Ribat Al Fath: } \\
\text { ramparts and doors; } \\
\text { Hassan mosque; } \\
\text { the Kasbah of Mehdiya } \\
\text { river front extension and } \\
\text { the construction of the } \\
\text { caliphate palace } \\
\end{array}$ & $\begin{array}{c}\text { Ribat Al Fath. The } \\
\text { urban plan is consoli- } \\
\text { dated by the establish- } \\
\text { ment of the connec- } \\
\text { tion axes between the } \\
\text { other gates and the } \\
\text { existing settlements } \\
\text { within the wall. Four } \\
\text { gates were built in the } \\
\text { Ribat Al Fath. Each } \\
\text { gate provides the } \\
\text { connection with the } \\
\text { exterior giving con- } \\
\text { tinuation to the city } \\
\text { routes and leading } \\
\text { to the neighbouring } \\
\text { regions of the Empire. } \\
\text { The gates, as well as } \\
\text { the walls, remained } \\
\text { on the urban } \\
\text { landscape of Rabat } \\
\text { in } 2014\end{array}$ & $\begin{array}{l} \\
\text { This period repre- } \\
\text { sents the first major } \\
\text { expansion of the city } \\
\text { and it should perhaps } \\
\text { be emphasised that } \\
\text { this kind of growth, } \\
\text { without significant } \\
\text { occupation, created } \\
\text { the uniqueness of } \\
\text { Rabat which is cha- } \\
\text { racterised by unoc- } \\
\text { cupied, wide open } \\
\text { spaces (Fig. 3) }\end{array}$ \\
\hline $\begin{array}{c}5^{\text {th }}: \text { Aribat } \\
\text { Al Moba- } \\
\text { rak Period } \\
(1253-1609)\end{array}$ & \begin{tabular}{|c|} 
\\
The Merinid \\
Dynasty \\
- Sultan \\
Yacoub \\
Youssouf and \\
Sultan Abou \\
Al Hassan \\
\end{tabular} & $\begin{array}{c}\text { The construction of } \\
\text { fortified walls on the } \\
\text { right bank, the region in } \\
\text { which there was an attack } \\
\text { by the Castilians in } 1265 . \\
\text { The Almohad urban area } \\
\text { was mostly neglected and } \\
\text { inaccessible ( } 80 \% \text { of the } \\
418 \text { hectars was undeve- } \\
\text { loped). The proposal for } \\
\text { a new Ribat, known as } \\
\text { Aribat Al Mobarak, con- } \\
\text { structed on the ancient } \\
\text { ruins of the Roman city } \\
\text { Sala. The construction } \\
\text { of walls and gates }\end{array}$ & \begin{tabular}{|} 
Fortified Ribat as \\
the mausoleum of \\
the dynasty. This \\
ensemble was known \\
as Chellah, in 2016 \\
\end{tabular} & $\begin{array}{l}\text { Apogee of Salé, } \\
\text { located on the right } \\
\text { bank and designated } \\
\text { as the main port, } \\
\text { economic and } \\
\text { urban centre }\end{array}$ \\
\hline
\end{tabular}


Table 3 (continued)

\begin{tabular}{|c|c|c|c|c|}
\hline $\begin{array}{l}\text { Morphologi- } \\
\text { cal period }\end{array}$ & $\begin{array}{c}\text { Historical } \\
\text { event }\end{array}$ & Innovation & Urban form & Outline view \\
\hline $\begin{array}{c}6^{\text {th: }} \text { The } \\
\text { Moors } \\
\text { Period } \\
(1609-1666)\end{array}$ & $\begin{array}{c}\text { The Saadian } \\
\text { Dynasty } \\
\text { - expul- } \\
\text { sion of the } \\
\text { Moors from } \\
\text { Spain as a } \\
\text { consequence } \\
\text { of religious } \\
\text { intolerance } \\
\text { (Lugan 2011) }\end{array}$ & $\begin{array}{l}\text { The expulsion of the } \\
\text { Moors led to a significant } \\
\text { influx of Muslim and } \\
\text { Jewish populations who } \\
\text { settled in the Kasbah } \\
\text { of Mehdiya and in the } \\
\text { adjacent southern area. } \\
\text { These differing ethnic } \\
\text { populations built their } \\
\text { own quarters and } \\
\text { founded their medina, } \\
\text { called New Salé. } \\
\text { The Kasbah was also } \\
\text { fortified and became the } \\
\text { centre of the municipal } \\
\text { power base, whilst Rabat } \\
\text { itself became the } \text { Premier } \\
\text { port in Morocco }\end{array}$ & \begin{tabular}{|c|} 
Medina of New Salé \\
- protected by a wall \\
in the south and was \\
divided into two the \\
large areas enclosed \\
by the earlier Almo- \\
had ramparts (Fig. 4) \\
The unexplored urban \\
space, within the \\
Almohad wall, was \\
dotted with agricultu- \\
ral areas and gardens \\
\end{tabular} & \begin{tabular}{|} 
New quarter (medina \\
or old city), called \\
New Salé, inside \\
the earlier Almohad \\
ramparts \\
Open spaces rested \\
with agricultural areas \\
and gardens
\end{tabular} \\
\hline $\begin{array}{l}7^{\text {th. }}: \text { Golden } \\
\text { Age Period } \\
(1666-1727) \\
\end{array}$ & \begin{tabular}{|} 
The Alaouite \\
dynasty \\
- Sultan \\
Moulay Ra- \\
chid (1666) \\
and Sultan \\
Moulay \\
Ismail (1672)
\end{tabular} & \begin{tabular}{|} 
Substantial \\
construction works: \\
1. New fortress (this \\
operated as a prison du- \\
ring the French Protec- \\
torate and as a Military \\
History Museum after \\
2010); \\
2. Prince's residence at \\
the Kasbah, which was \\
completed during the \\
reign of Moulay Ismail. \\
After Meknès, the pa- \\
lace became the second \\
residence of the dynasty
\end{tabular} & \begin{tabular}{|c|} 
No major change \\
occurred in the formal \\
urban plan (although \\
this period was politi- \\
cally and historically \\
important) thus mar- \\
king a phase of urban \\
development that \\
reflected the political \\
stagnation through \\
which the country \\
was passing
\end{tabular} & $\begin{array}{c}\text { Period of stagnation } \\
\text { - consolidation of } \\
\text { inner fringe belt }\end{array}$ \\
\hline $\begin{array}{c}8^{\text {th }}: \text { Expan- } \\
\text { sion and } \\
\text { Consolida- } \\
\text { tion Period } \\
(1757-1912)\end{array}$ & \begin{tabular}{|c} 
The Alaouite \\
dynasty - \\
Sultan Sidi \\
Mohammed \\
ben Abdallah
\end{tabular} & $\begin{array}{l}\text { 1. Construction of two } \\
\text { sqalas (military surveil- } \\
\text { lance towers); } \\
\text { 2. Construction of a new } \\
\text { royal palace located wit- } \\
\text { hin the southeast walls } \\
\text { and with a rampart to the } \\
\text { new Royal Alaouite Kas- } \\
\text { bah, in the } 19^{\text {th }} \text { century; }\end{array}$ & \begin{tabular}{|} 
Innovations are repre- \\
sented in the figure \\
below, showing the \\
transformation in the \\
urban form
\end{tabular} & $\begin{array}{c}\text { This period repre- } \\
\text { sents the second } \\
\text { great expansion in the } \\
\text { urban development } \\
\text { and followed the same } \\
\text { tendency towards } \\
\text { grandness by leaving } \\
\text { wide open spaces } \\
\text { unoccupied }\end{array}$ \\
\hline
\end{tabular}


Table 3 (continued)

\begin{tabular}{|c|c|c|c|c|}
\hline $\begin{array}{l}\text { Morphologi- } \\
\text { cal period }\end{array}$ & $\begin{array}{c}\text { Historical } \\
\text { event }\end{array}$ & Innovation & Urban form & Outline view \\
\hline $\begin{array}{c}8^{\text {th }} \text { : Expan- } \\
\text { sion and } \\
\text { Consolida- } \\
\text { tion Period } \\
(1757-1912)\end{array}$ & \begin{tabular}{|c} 
Sultan Mo- \\
ulay Abder- \\
rahmane Ben \\
Hicham; \\
Sultan Mo- \\
ulay Slimane
\end{tabular} & $\begin{array}{l}\text { 3. Creation of protected } \\
\text { new residential neighbo- } \\
\text { urhoods in the north-we- } \\
\text { stern part of the urban } \\
\text { area; } \\
\text { 4. Installation of Royal } \\
\text { gardens, southeast of the } \\
\text { Royal Palace, known as } \\
\text { Agdal (Agdal means gar- } \\
\text { den in arabic); } \\
\text { 5. Construction of a se- } \\
\text { condary royal residence } \\
\text { facing the Atlantic Oce- } \\
\text { an on the new north-we- } \\
\text { stern urban space; } \\
\text { 6. Foundation of the } \\
\text { Jewish neighbourhoods, } \\
\text { called Mellahs, in Rabat } \\
\text { and Salé }\end{array}$ & $\begin{array}{l}\text { Urban occupation } \\
\text { during the Alaouite } \\
\text { dynasty } \\
\text { Source: Map produced } \\
\text { by the author based } \\
\text { on historical research, } \\
2014\end{array}$ & $\begin{array}{l}\text { The Alaouites had the } \\
\text { intention of turning } \\
\text { Rabat, once again, } \\
\text { into the third imperial } \\
\text { capital after Marra- } \\
\text { kesh and Fès }\end{array}$ \\
\hline $\begin{array}{c}9^{\text {th }} \text {. French } \\
\text { Protecto- } \\
\text { rate Period } \\
\text { - Prost } \\
\text { urban plan } \\
(1912-1941)\end{array}$ & $\begin{array}{c}\text { The French } \\
\text { Protectorate } \\
\text { (from 1912 } \\
\text { to 1956) }\end{array}$ & $\begin{array}{c}\text { Designed by Henri } \\
\text { Prost, a French urban } \\
\text { planner, the modernist } \\
\text { project respected the } \\
\text { integrity of the traditio- } \\
\text { nal fabric, while at the } \\
\text { same time applying the } \\
\text { most modern rules of } \\
\text { urbanism. Thus, although } \\
\text { the multiple city walls } \\
\text { presented in the urban } \\
\text { extensions remained, the } \\
\text { project represented the } \\
\text { first urban master plan of } \\
\text { the city, covering a total } \\
\text { of } 770 \text { hectares and with } \\
\text { zoning restricted to three } \\
\text { sectors: residential and } \\
\text { commercial conference } \\
\text { centre (35\%); govern- } \\
\text { ment (5.2\%); individual } \\
\text { housing ( } 44.2 \%) ; \text { Medina } \\
\text { of Rabat (15.6\%) }\end{array}$ & $\begin{array}{c}\text { While planning the } \\
\text { new capital, only } \\
\text { the traditional urban } \\
\text { fabric (Medina and } \\
\text { Kasbah) remained. } \\
\text { The intention of the } \\
\text { new urban settlement } \\
\text { was to occupy the } \\
\text { underused area within } \\
\text { the Almohad wall } \\
\text { which had previously } \\
\text { been occupied by } \\
\text { extensive plantations } \\
\text { and gardens and the } \\
\text { residential sector that } \\
\text { had been created by } \\
\text { the Alauite Sultans. } \\
\text { The wall of the Alaui- } \\
\text { te dynasty was pulled } \\
\text { down to make way for } \\
\text { the new perimeter of } \\
\text { the modern city }\end{array}$ & $\begin{array}{l}\text { Transformation of the } \\
\text { city of RibatAlFath } \\
\text { into the capital Rabat, } \\
\text { planned over the same } \\
\text { geographical area } \\
\text { limits } \\
\text { The Salé region was } \\
\text { not included within } \\
\text { the perimeter. This } \\
\text { event marked the } \\
\text { separation between } \\
\text { the two sides } \\
\text { At this period was } \\
\text { form most of the } \\
\text { middle fringe belts } \\
\text { (MFB) }\end{array}$ \\
\hline
\end{tabular}

Source: Conceived by the authors based on S. Safe, S. Pereira Costa (2014). April, 2016. 
The middle fringe belts were formed after two major city expansions. Wide open spaces were created along with the urban occupation for more than one time ambition of turning Rabat into a great Empire base. Open spaces rested with agricultural areas and gardens, which has characterize and given an identity to Rabat. By the time the French has come to colonize the country, Rabat presented a solid traditional urban fabric, that was protected by General Lyautey. He invited a French urban planner and landscape designer to create a system of parks using most of the open areas left as gardens and agriculture. For this, the new capital was born over the same geographical limits as the existing city, but totally re-planned. At this point, the open spaces got different land uses and appropriation, forming the second (larger) middle belt. In Fig. 5 we can see the MFB.

Year: 1757

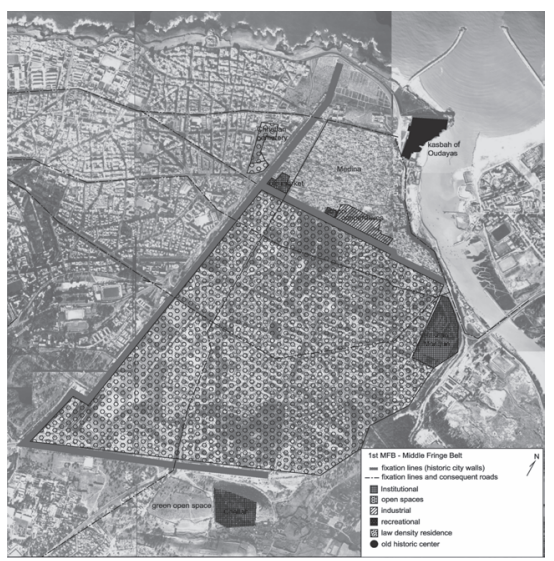

Year: 1912

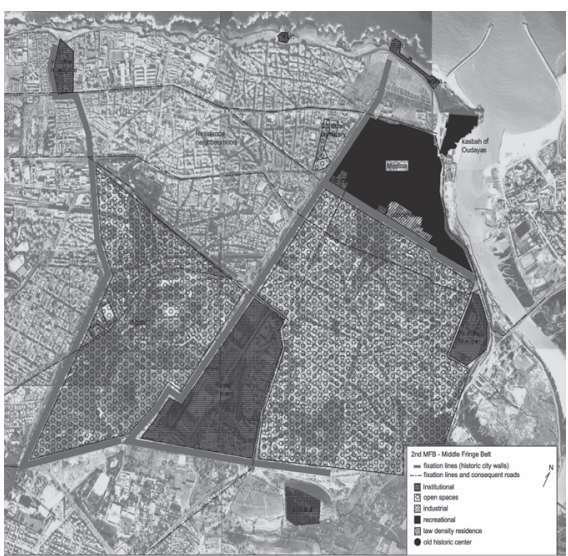

Year: 1941

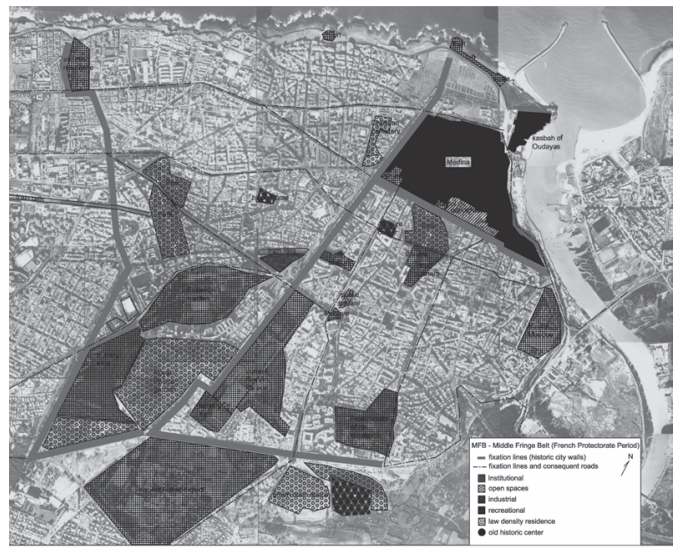

Fig. 5. Expansion Stage - Middle fringe belt formation (MFB)

Source: Map produced by the author based on historical research (2016) 
The third sub-section contains the last three morphological periods (Table 4) and a map of the OFB (Fig. 6).

Table 4

Chart with $10^{\text {th }}$ to $12^{\text {th }}$ morphological periods of Rabat

\begin{tabular}{|c|c|c|c|c|}
\hline $\begin{array}{l}\text { Morphologi- } \\
\text { cal period }\end{array}$ & $\begin{array}{c}\text { Historical } \\
\text { event }\end{array}$ & Innovation & Urban form & Outline view \\
\hline $\begin{array}{c}10^{\text {th }}: \\
\text { Period of } \\
\text { expansion: } \\
\text { Ecochard } \\
\text { urban plan } \\
(1956-1972)\end{array}$ & $\begin{array}{c}\text { French } \\
\text { Protectorate } \\
\text { (from } 1912 \\
\text { to 1956) }\end{array}$ & $\begin{array}{l}\text { 1. Expansion desig- } \\
\text { ned by urban planner } \\
\text { M. Ecochard for four } \\
\text { housing programs to } \\
\text { replace the existing } \\
\text { slums. Design standar- } \\
\text { dized as Islamic mo- } \\
\text { del that included the } \\
\text { mosque, public bath, } \\
\text { school and market; } \\
\text { 2. Construction of the } \\
\text { highway connecting } \\
\text { the city to the airport } \\
\text { in Sale and other road } \\
\text { networks, for better } \\
\text { access to leisure areas } \\
\text { (golf and hippodrome) }\end{array}$ & $\begin{array}{l}\text { The Urban expansion } \\
\text { along the radial axes } \\
\text { led to the creation } \\
\text { of a ring road which } \\
\text { facilitated enhanced } \\
\text { connection between } \\
\text { both growing cities }\end{array}$ & $\begin{array}{l}\text { Period of expansion } \\
\text { for housing programs } \\
\text { designed as the Isla- } \\
\text { mic fabric. } \\
\text { Creation of fixation } \\
\text { line: highway Rabat } \\
\text { to the airport in Salé }\end{array}$ \\
\hline $\begin{array}{c} \\
11^{\text {th. }} \text { Inde- } \\
\text { pendence: } \\
\text { Rabat-Sale } \\
\text { urban master } \\
\text { plan of } \\
1971-72 \\
\end{array}$ & $\begin{array}{c}\text { The Alaouite } \\
\text { dynasty - King } \\
\text { Hassan II } \\
\text { (1961-1999). } \\
\text { The end of } \\
\text { the French } \\
\text { Protectorate. } \\
\text { A nationalist } \\
\text { attempted } \\
\text { coup in 1971 } \\
\text { and 1972, } \\
\text { during which } \\
\text { Hassan II } \\
\text { ruled the } \\
\text { kingdom with } \\
\text { dictatorial } \\
\text { powers }\end{array}$ & $\begin{array}{l}\text { 1. 1971-72 Rabat- } \\
\text {-Salé's Master Plan to- } \\
\text { gether with the objective } \\
\text { of developing roads and } \\
\text { transport; } \\
\text { 2. From the } 80 \text { 's, the } \\
\text { Agdal neighbourhood } \\
\text { was regenerated with } \\
\text { the inclusion of a busi- } \\
\text { ness centre: partly oc- } \\
\text { cupied by offices and } \\
\text { large upper middle class } \\
\text { apartments, parking and } \\
\text { amenities; } \\
3 . \text { A Program for } \\
\text { the grassy spaces was } \\
\text { drawn up which boa- } \\
\text { sted a green corridor be- } \\
\text { tween the beach and the } \\
\text { central area of Temara, } \\
\text { a northern metropolitan } \\
\text { city, and a greenbelt of } \\
1200 \text { hectars }\end{array}$ & $\begin{array}{l}\text { The urban form } \\
\text { underwent great cen- } \\
\text { trifugal expansion, } \\
\text { almost reaching the } \\
\text { administrative limits } \\
\text { of Rabat and Salé. } \\
\text { During this period } \\
\text { the metropolitan } \\
\text { formation of Temara } \\
\text { and Skhrirat began } \\
\text { and there was also } \\
\text { an expansion in park } \\
\text { and green belt areas }\end{array}$ & $\begin{array}{l}\text { The post-independence } \\
\text { period was marked by: } \\
\text { - great urban expan- } \\
\text { sion (urban population } \\
\text { doubled - from } 550,800 \\
\text { to } 1,174,100 \text { inhabitants } \\
\text { according SDAU 1991) } \\
\text { together with the rapidly } \\
\text { increasing demand for } \\
\text { housing (PAU, 2009); } \\
\text { - informal urbaniza- } \\
\text { tion on the slopes of the } \\
\text { Bouregreg river valley, } \\
\text { as well as public and } \\
\text { private initiatives for set- } \\
\text { tlements on large urban } \\
\text { plots; } \\
\text { * Such growth made } \\
\text { the state aware of the } \\
\text { need for comprehensive } \\
\text { planning. The 1st master } \\
\text { plan of the Rabat-Sale } \\
\text { conurbation was made } \\
\text { in } 1971-72\end{array}$ \\
\hline
\end{tabular}


Table 4 (continued)

\begin{tabular}{|c|c|c|c|c|}
\hline $\begin{array}{c}\text { Morphologi- } \\
\text { cal period }\end{array}$ & $\begin{array}{c}\text { Historical } \\
\text { event }\end{array}$ & Innovation & Urban form & Outline view \\
\hline $\begin{array}{c}12^{\text {th }}: \text { Rabat- } \\
\text {-Sale urban } \\
\text { master plan } \\
\text { of } 1991\end{array}$ & $\begin{array}{c}\text { The Alaouite } \\
\text { dynasty } \\
\text { - King } \\
\text { Hassan II } \\
\text { (1961-1999); } \\
\text { King Mo- } \\
\text { hammed VI } \\
\text { (1999-2014) }\end{array}$ & $\begin{array}{c}\text { The current Rabat-Salé } \\
\text { Master Plan } 1991 . \\
\text { From } 1980 \text { to the } \\
\text { present, expansion has } \\
\text { taken place along the } \\
\text { coastal and outlying } \\
\text { areas. } \\
\text { Some neighbourhoods } \\
\text { have experienced } \\
\text { a higher growth in } \\
\text { population density } \\
\text { than others }\end{array}$ & $\begin{array}{c}\text { Currently there is less } \\
\text { urban expansion and } \\
\text { a major consolidation } \\
\text { of the existing structu- } \\
\text { re is evident }\end{array}$ & $\begin{array}{l}\text { King Mohammed VI } \\
\text { brought new vision to } \\
\text { urban development, } \\
\text { increasing tourism, } \\
\text { engendering political } \\
\text { openness and priori- } \\
\text { tising the protection } \\
\text { of national heritage } \\
\text { and the inclusion of } \\
\text { underprivileged people } \\
\text { in urban areas. } \\
\text { * The idea of promo- } \\
\text { ting Rabat as } \\
\text { a UNESCO World } \\
\text { Heritage Site candida- } \\
\text { te was born }\end{array}$ \\
\hline
\end{tabular}

Source: conceived by the authors based on S. Safe, S. Pereira Costa (2014). April, 2016.

This is a consolidation period according to our analysis, although the urban site underwent great centrifugal expansion, reaching the nowadays administrative limits of Rabat. There was also an expansion in park and green belt areas, given continuity to the park system concept and establishing the city boundaries. The OFB were formed along with two fixation lines: the highway that connects Casabanca-Salé; and a light rail that connects the new neighbourhoods to the modern centre and medina.

The university campus in Agdal reflects the initial formation of the outer fringe belt possessing an institutional and low density character which follows the southwest expansion axis, parallel to the waterfront. The location of this fringe belt is consistent with the sequence of parks previously deployed in the nearby area of Agdal. This element points towards the formation of other units of outer fringe belts that formed a centre line instead of a belt.

Fig. 6 presents the outer fringe belt. A map compilation of the three phases (IFB, MFB, OFB) is presented in Fig. 7. 


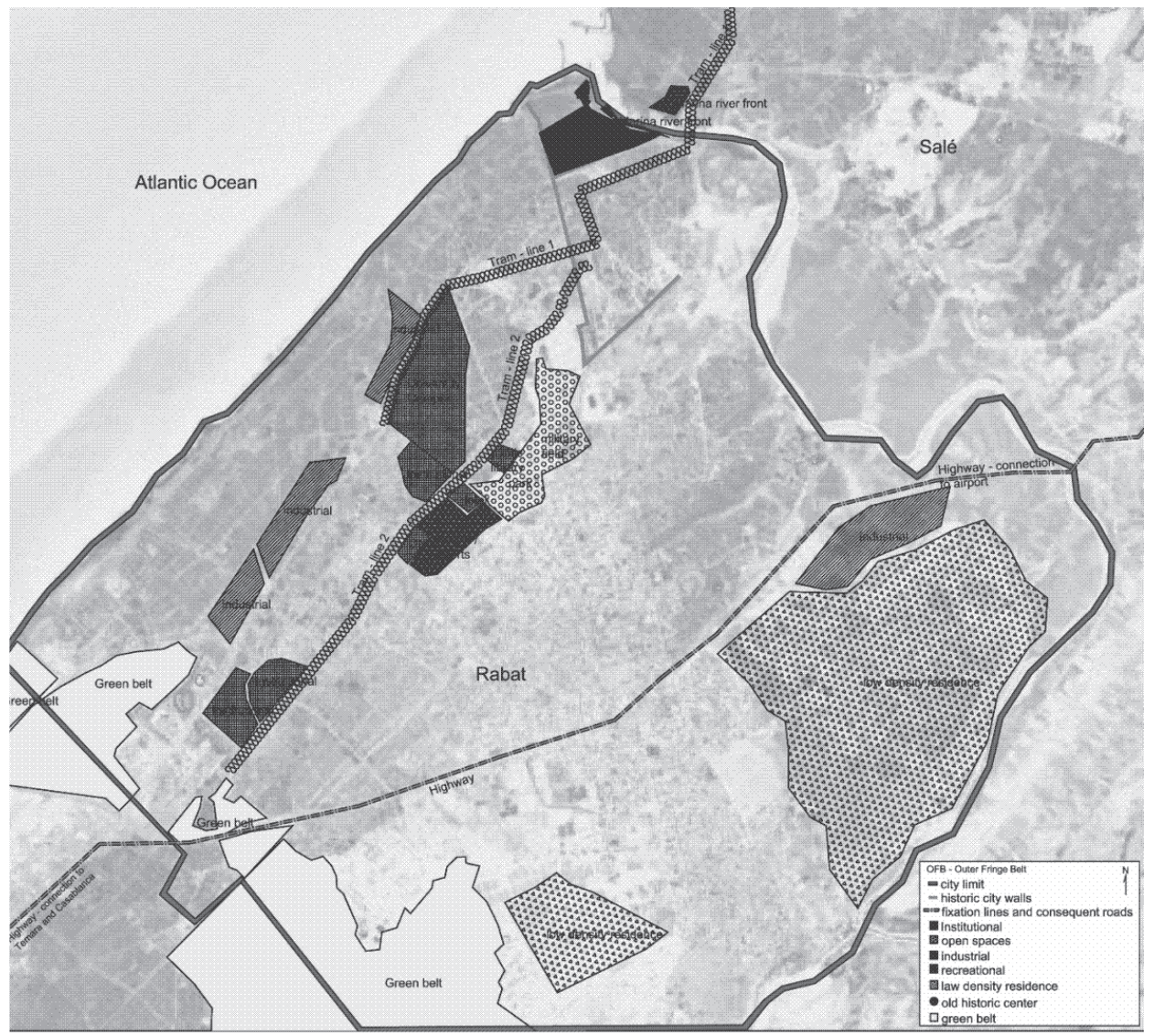

Fig. 6. Consolidation Stage - Outer fringe belt formation (OFB)

Source: Map produced by the author based on historical research, 2016 


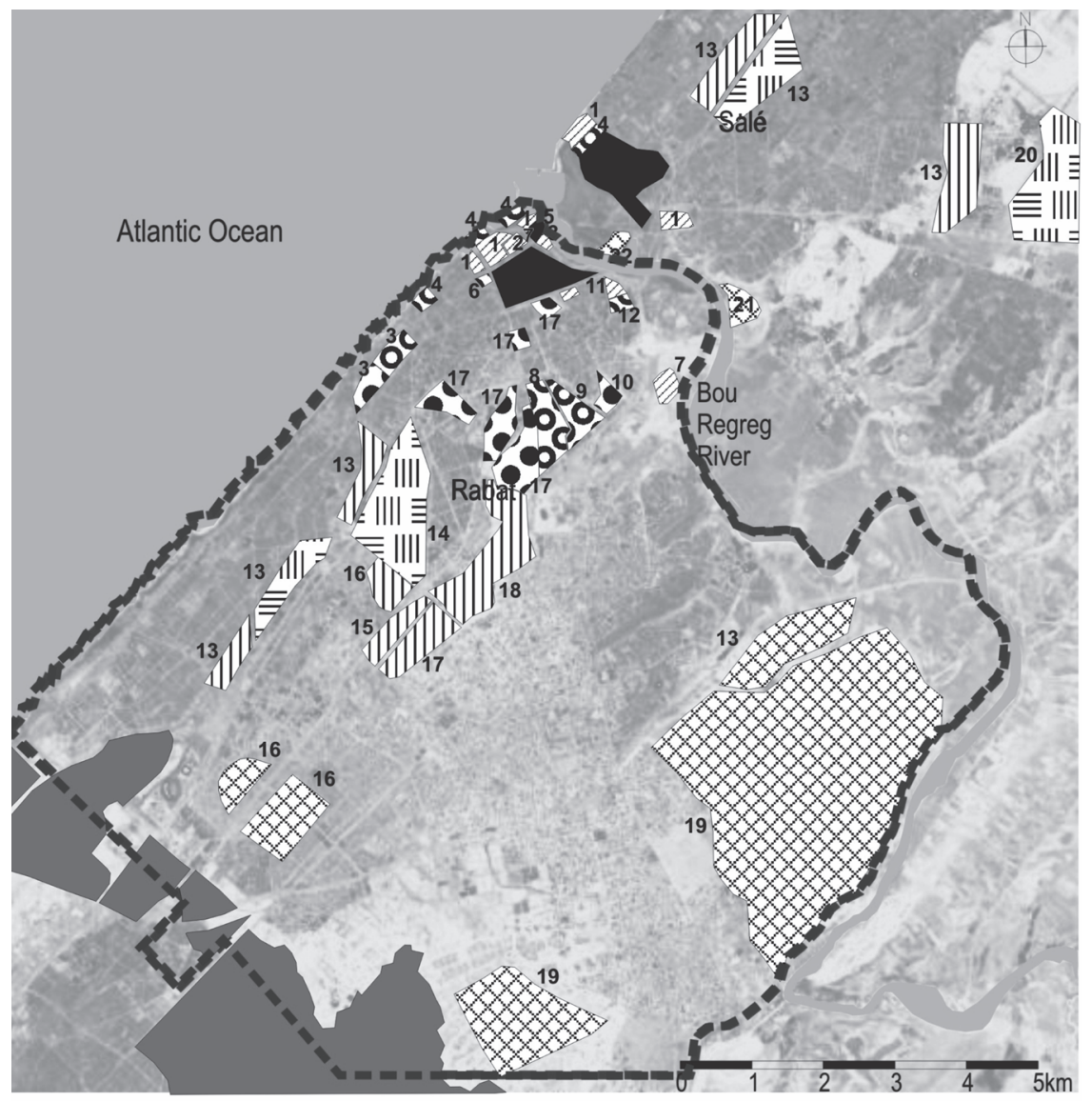

Legend: Fringe belts in Rabat

Historic islamic center

Forest/ green belt

| até $1727|1757-1912| 1912-1941|1941-1956| 1960-1990|1990-2014|$

inner Fringe belt

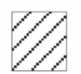

Middle Fringe belt

:0:

Outer Fringe belt

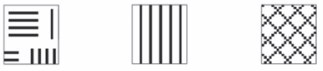

legenda unldades hlatos urbanos:

1. Muslim cemitery

2. Militar fort/museum

3. Ancient Royal palace

4. Fort/sqala

5. Carpet association

6. Christian cemitery
7. Archeological traces

8. Royal palace

9. Kasbah touarga

10 Protectorate oficial residence

11. Hassan mosque

12.Mausoleum

13. Industrial site
14.University campus
15.ONU
16. Institutional public site
17.Parks
18. Military zoning

19. Low density residence

20. Airport

21. Theater

22. Leisure/ marina river front

Fig. 7. Fringe Belts of Rabat

Source: Map produced by the author based on historical research, 2016 
After analyzing the fringe belts formation, we can pass to the understanding on how fringe belts can help providing the recognition of a historical landscape.

\section{Fringe belt and the historic boundaries of Rabat}

The initial fixation stage is represented by an inner fringe belt which houses a muslin cemetery, a fort, an ancient fort/prison, an ancient royal palace with garden (a museum from 2014) and a Marina promenade (old port). The IFB separates the two traditional urban fabrics (Kasbah of Oudayas and Medina), revealing the Kasbah as the traditional urban core and showing that this small scale settlement represents a great relationship with its territory (a geographical promontory for military use, in different history stages) and its integrity through time. This first urban development site embraced by the inner fringe belt could, alone, demonstrates criteria (v).

The expansion stage shows middle fringe belts being formed after two different periods of city growth: after the moors and during the French Protectorate period when Ribat Al Fath was transformed into the capital city of Rabat. These rings are found in two different rays - outside the Medina (Moors) and close to the French Protectorate capital boundary. We consider the case of Rabat to be quite an interesting one, first for having undergone a process of inter-racial-cultural occupation (Berber, Arab and Western Europe) and secondly, for the fact that the city has had hygienic and modern urban occupation which, at the same time, has respected the particularity of the place and the uniqueness of its character.

The footprint of the new capital area has overlapped the previous urban sprawl creating new and contrasting existing urban fabric, albeit, inserted into a previously occupied territory. Despite the absence of political and economic stagnation during this period, the registering of middle fringe belt has taken place through the compartmentalization of the modern city in a clear restructuring of the underused in-house spaces. In the new project, the arteries of the new town align the axes of the Medina and the monuments and the zoning provides for the establishment of green, low-density units that have become middle fringe belts located within a consolidated urban structure.

The middle fringe belts reveal two others historical regions hierarchy: the first MFB around the Medina marks the footprint of an older and traditional historic centre; the second MFB shows the French Protectorate capital limit.

All together, IFB \& MFB, show the configuration of a possible Historic Urban Landscape structure (a different and new UNESCO heritage category).

The following map (Fig. 8) presents the historical zones in which the city has evolved over time, comparing the proposed limits with the fringe belts positions (IFB, MFB, OFB). 


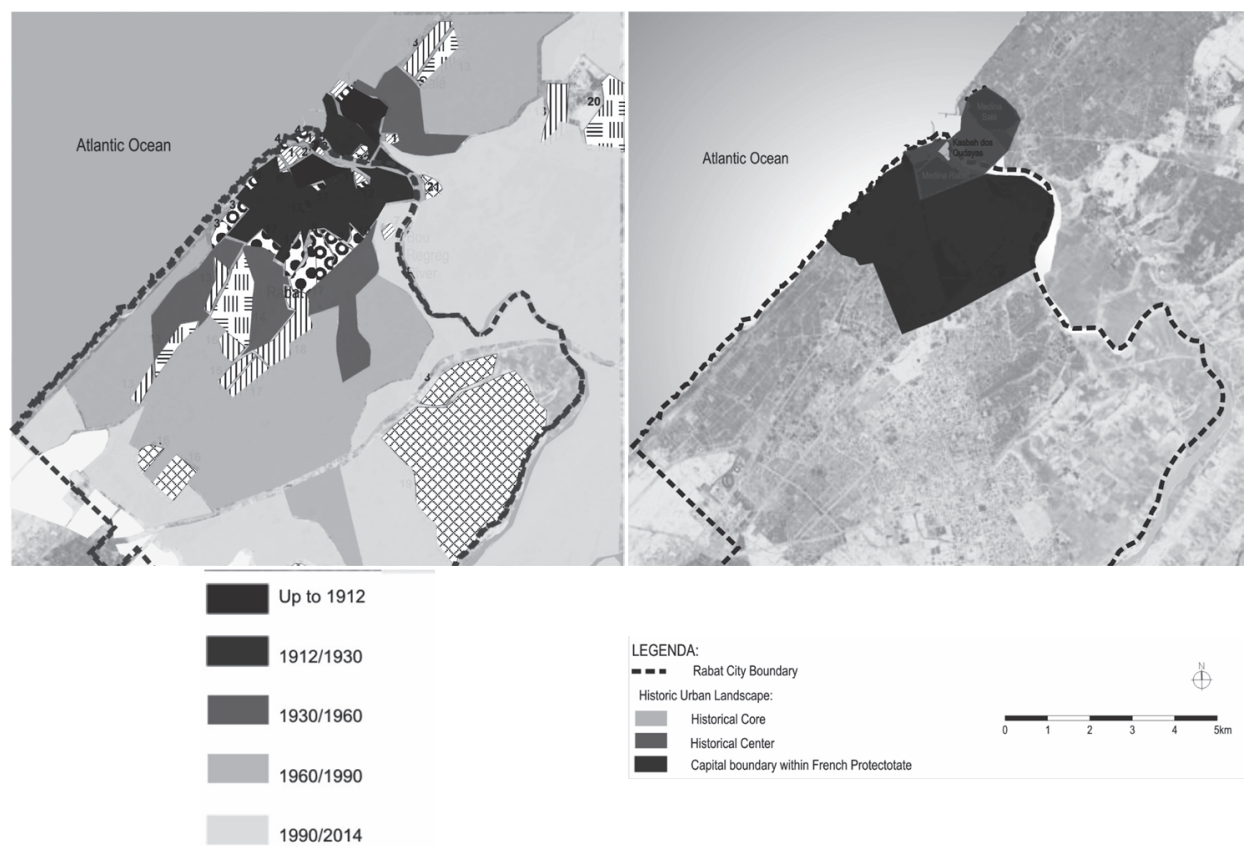

Fig. 8. Left: Fringe Belts historical regions

Right: historical hierarchy within this landscape proposal

Source: Map produced by the author based on historical research, 2014

From the analysis of urban evolution, the consolidation period has being identified as a lower stratification of layers and thus less historicity. This also generates the conclusion that it is possible to identify a historical hierarchy composed of historical core, centre and urban landscape, understanding that the older nucleus presents more stratification of layers and for so, more historicity.

\section{Conclusion}

This case study of morphological urban evolution together with fringe belts development analysis have proved to be a valuable method for interpreting landscape and understanding the meanings of the urban shape. This combined analysis can facilitate specifying the boundary of the historical centers. In so doing, it can thus contribute to the heritage management and preservation of the site.

Significantly, the research carried out on Rabat's establishment, expansion and consolidation phases proves that the Kasbah of Oudayas was the first Islamic urban nucleus in the capital and has been "protected" by the inner fringe belt. The Kasbah thus qualifies as a potential candidate for meeting the fifth criterion 
and its existence directly challenges UNESCO's grounds for rejection in 2012. Furthermore, the analysis of urban evolution, presented here, has demonstrated the site's connection with a diversity of cultures which include Berbers, Arabs and Westerners, while the natural promontory fortified position suggests a relationship between the original form of military fortification and the operational environment. These characteristics, it is important to emphasise, are all in accordance with further elements of UNESCO's fifth criteria.

Understanding the limits established by the fringe belts also provide recognition of the historical landscape. We therefore come to the conclusion that by acknowledging and analyzing the fringe belt elements in the urban structure it is possible to demonstrate the settlement's relationship with its territory, demonstrating that there is no fragmentation neither privileged relationship with a particular environment, as the fringe belts reveal the regions as an ensemble between the different stages of development.

Finally and on a more general note, by acknowledging and analyzing the fringe belt elements in the urban structure it has been possible to identify a historical hierarchy constituted by historical core, centre and urban landscape. Each landscape has, as demonstrated in this case study, its own character, management and conservation requirements and should be considered and cared for as an ensemble composed of differing elements and not as fragments bounded together for management, as occur nowadays being World Culture Heritage at UNESCO.

\section{Acknowledgements}

The authors acknowledged the support received from the Fundação de Amparo à Pesquisa de Minas Gerais - FAPEMIG, from the Conselho Nacional de Desenvolvimento Cientifico e Tecnológico - CNPq and Coordenação de Aperfeiçoamento de Pessoal de Nível Superior - CAPES to develop this research and to present this paper.

\section{LITERATURE}

Brignon J., Amine A., Boutaleb B., Martinet G., Rosenberger B., 1987, Histoire du Maroc, Colaboração de Michel Terrasse, Hatier.

Caillé J., 2006, La ville de Rabat jusqu'au Protectorat Français: histoire et archéologie, Vol. 1, Editions Frontispice, Casablanca.

Conzen M.P., 2004, Thinking about urban form: Papers on Urban Morphology, 19321998, Peter Lang, Oxford.

Conzen M.P., 2009, How growing cities internalize their old urban fringes: a cross cultural comparison, „Journal of the International Seminar on Urban Form”, 13(1), Dorchester, s. 29-54.

Conzen M.R.G., 1969, Alnwick, Northumberland: a study in town-plan analysis, LTD Institute of British Geographers, London, Alden \& Mowbray, Alden Press, Oxford. 
Es-Semmar M., 2011, L'évolution de la courbe urbanistique et historique de la ville de l'estuaire de Bouregreg Sala-Ribat Al Fath durant les 25 derniers siècles, Royame du Maroc, Rabat, Agence pour l'Aménagement de la Vallée du Bouregreg. Non Published Document.

Icomos 1401, 2011, http://whc.unesco.org/uploads/nominations/1401.pdf (Acess: april 2016.)

Lugan B., 2011, Histoire du Maroc: des origines à nous jours, Ellipses Éition Marketing S.A., Paris.

Plan d'Aménagement Unifié de la Ville de Rabat (PAU), 2009, Mission 2: Diagnostic Analyses thématiques et spatiales Royaume du Maroc, Ministère de l'Habitat, de l'Urbanisme et de l'Aménagement de l'Espace, Agence Urbaine de Rabat-Salé, Atelier parisien d'urbanisme.

Safe S., Pereira Costa S., 2014, Urban Evolution analysis as a means to confirm an outstanding example of a traditional human settlement in Rabat, [in:] Oliveira V., Pinho P., Batista L., Patatas T. and Monteiro C. (eds.), Our common future in Urban Morphology, FEUP, Porto.

\section{ANALIZA FRINGE BELT: METODA POTWIERDZAJĄCA UTWORZENIE HISTORYCZNYCH GRANIC RABATU}

Zarys treści Fringe belt, czyli rozlegle obszary o małej gęstości zabudowy i znacznej ilości przestrzeni otwartych przeznaczonych pod zagospodarowanie instytucjonalne, stanowią ważny morfologiczny element krajobrazu miast. Rabat, stolica Maroka, w 2012 roku został wpisany na listę światowego dziedzictwa UNESCO pod nazwą „Rabat - nowoczesna stolica i historyczne miasto", jako że reprezentuje model planowania nowoczesnego zintegrowany z historycznym jądrem osadniczym. Niemniej kryterium (v) - przyznawane wybitnym przykładom tradycyjnego osadnictwa, reprezentującego kulturę (lub kultury) lub interakcję człowieka z otoczeniem - zostało uznane za podstawę odrzucenia nominacji Rabatu, który według raportu ICOMOS jest zdefragmentowany przestrzennie i wykazuje brak związku między zabudową a środowiskiem. Mając na uwadze powyższe, artykuł prezentuje Kasbah of Oudayas, unikalną i wyróżniającą się historyczną jednostkę osadniczą, będącą zaprzeczeniem przykładów zaprezentowanych w 2012 roku.

Celem opracowania jest zbadanie rozwoju przestrzennego Rabatu w różnych okresach morfologicznych w celu ustalenia, czy fringe belts mogą ujawnić historyczne obszary, w obrębie których miasto ewoluowało w czasie. Artykuł jest także próbą zrozumienia, w jaki sposób fringe belts mogą przyczynić się do uznania Kasbah of Oudayas za pierwsze islamskie jądro osadnicze stolicy. Autorzy wyrażają nadzieję, że niniejsze opracowanie może okazać się pomocne tak dla naukowców, jak i praktyków w dziedzinie morfologii miast i dziedzictwa kulturowego; dostarczyć wskazówki, w jaki sposób badać wyjątkowe historyczne 
jednostki osadnicze oraz uwyraźnić ich architektoniczne, historyczne i kulturowe wartości; wykazać, w jaki sposób zastosowanie i upowszechnianie wskazanej metodologii może otworzyć nowe perspektywy dla badań z zakresu morfologii miast.

Słowa kluczowe Morfologia miast, fringe belts, rozwój obszarów miejskich, światowe dziedzictwo UNESCO.

Simone Marques de Sousa Safe Architect and Urban Planner (PUC-MG)

MSC em Ambiente Construído e Patrimônio Sustentável - MACPS Escola de Arquitetura Universidade Federal de Minas Gerais, Brasil

Associate Professor Staël de Alvarenga Pereira Costa Architect and Urban Planner (EAUFMG) Department of Urbanism

Escola de Arquitetura Universidade Federal de Minas Gerais, Brasil 